\title{
Adherence to inhalers and associated factors among adult asthma patients: an outpatient- based study in a tertiary hospital of Rajshahi, Bangladesh
}

Md. Abdur Rafi, ${ }^{1,2}$, Chowdhury Ibtida Tahmin ${ }^{3}$, Symom Tashrik4, Atia Sharmin Bonna ${ }^{5}$, Ferdousy Jannat ${ }^{5}$, Sabrina Jahan Mily ${ }^{6}$, Abhigan Babu Shrestha ${ }^{7}$, Senjuti Seemanta ${ }^{7}$, Afsana Rashid ${ }^{8}$, Mosarrat Mahjabeen $^{8}$, Nurunnahar Nura ${ }^{9}$, Tasnim Shahriar ${ }^{10}$, Ashrafur Rahaman Mahadi ${ }^{11}$, Kawser Ahmed ${ }^{12}$,

Mohammad Jahid Hasan ${ }^{2 *}$, Md. Azizul Haque ${ }^{1}$ and Md. Golam Hossain ${ }^{13}$

\begin{abstract}
Background: Adherence to inhaler medication is an important contributor to optimum asthma control along with adequate pharmacotherapy. The objective of the present study was to assess self-reported adherence levels and to identify the potential factors associated with non-adherence to the inhalers among asthma patients.

Methods: This facility-based cross-sectional study was conducted in the medicine outpatient department of Rajshahi Medical College Hospital from November 2020 to January 2021. A total of 357 clinically confirmed adult asthma patients were interviewed. Inhaler adherence was measured using the 10-item Test of Adherence scale (TAI).. Both descriptive and inferential statistics were used to express the socio-demographic of the patients and predictors of poor adherence to inhaler.
\end{abstract}

Results: A substantial number of participants were non-adherent (86\%) to inhaler medication. Patients non-adherent to inhaler medication are often younger $(23.15,95 \% \mathrm{Cl} 3.67-146.08)$, lived in the rural area (23.28, 95\% Cl 2.43-222.66), less year of schooling $(5.69,95 \% \mathrm{Cl} 1.27-25.44)$, and belonged to the middle income (aOR 9.74, 95\% Cl 2.11-44.9) than those adherent with the inhaler. The presence of comorbidities $(12.91,95 \% \mathrm{Cl} 1.41-117.61)$, prolonged duration of inhaler intake $(5.69,95 \% \mathrm{Cl} 1.22-26.49)$, consulting non-qualified practitioners $(13.09,95 \% \mathrm{Cl} 3.10-55.26)$ were the significant contributor of non-adherence.

Conclusion: Despite ongoing motivation and treatment, non-adherence to inhalation anti-asthmatic is high and several factors have been found to contribute. Regular monitoring and a guided patient-centered self-management approach might be helpful to address them in long run.

Keywords: Asthma, Inhaler, Adherence, Obstructive lung disease, Anti-asthmatic agents, Medication nonadherence, Drug compliance

*Correspondence: dr.jahid61@gmail.com

2 Pi Research Consultancy Center, Dhaka, Bangladesh

Full list of author information is available at the end of the article

\section{Background}

Asthma is a heterogeneous disease, usually characterized by chronic airway inflammation, bronchial reversible obstruction, and hyperresponsiveness to direct or indirect stimuli [1]. Every year almost 495 million deaths original author(s) and the source, provide a link to the Creative Commons licence, and indicate if changes were made. The images or other third party material in this article are included in the article's Creative Commons licence, unless indicated otherwise in a credit line to the material. If material is not included in the article's Creative Commons licence and your intended use is not permitted by statutory regulation or exceeds the permitted use, you will need to obtain permission directly from the copyright holder. To view a copy of this licence, visit http://creativecommons.org/licenses/by/4.0/. The Creative Commons Public Domain Dedication waiver (http://creativeco mmons.org/publicdomain/zero/1.0/) applies to the data made available in this article, unless otherwise stated in a credit line to the data. 
occur worldwide from this chronic respiratory disease [2]. The prevalence is increasing by $50 \%$ every decade, especially in the low and middle-income countries of the South-East Asian region [3, 4]. In Bangladesh, a lowermiddle-income country of this region, more than eight million people are suffering from asthma that constituents almost 5.2\% of the total population [5].

Successful asthma management depends on several drugs and patient-related factors like age, smoking, environmental and occupational factors, asthma-related comorbidities, choice of drug and device, patients' adherence to the prescribed medications, and their inhaler handling techniques [6]. Inhalation therapy remains the mainstay of asthma management mostly due to its rapid onset of action, high therapeutic efficacy, and lower systemic adverse effects [6-8]. Inhaled corticosteroids along with short or long-acting beta-2 agonists and/or anticholinergic agents are most commonly prescribed as the first-line treatment for controlling asthma [8]. However, despite adequate pharmacotherapy, the control of asthma often has shown suboptimal as only prescribing appropriate medication is not adequate for achieving optimum asthma control. The Global Strategy for Asthma Management and Prevention adopted by the Global Initiative for Asthma (GINA) recommended a patient-caregiver partnership and guided self-management, along with adequate drug therapy for achieving long-term control and decreasing the frequency of exacerbation of asthma [7]. In this patient-centered approach, increasing adherence to the prescribed inhalation therapy is highly emphasized as it was evidenced that almost half of the patients with chronic diseases fail to take their long-term medications as directed at least part of the time [7,9]. Non-adherence to the prescribed medications is an important contributor to uncontrolled asthma as well as increased healthcare utilization and increased cost [7, 10-12]. The rate of adherence varies across the country and also exists in between the age and sex groups [13]. Almost 43\% of asthma patients worldwide are non-adherent to their inhalation therapy [14]. However, some studies suggest that the rate may be as high as $87 \%$ among patients with severe asthma $[15,16]$. A number of personal and socioeconomic factors including patients' perception about the disease and medications, fear of side effects, patientprovider communication quality, family and social support as well as cost and availability of the drugs may influence the adherence of patients to their prescribed treatment $[11,12,14]$.

Addressing non-adherence to the inhalation therapy should be a priority in the clinical assessment of asthma patients, especially those who have difficult-to-control asthma, and addressing non-adherence is likely to have greater benefits in this group than any novel treatment
[17]. Despite this fact, there is hardly any evidence on adherence to asthma medication and its influencing factors among patients of Bangladesh. Moreover, using the non-validated or generalized tool for adherence assessment may invariably underestimate the incidence of non-adherence rates to the inhalers among asthma patients [9]. Hence, the present study aimed to assess self-reported adherence level and to identify the potential factors associated with non-adherence to the inhalers among asthma patients.

\section{Methods \\ Study design and participants}

This facility-based cross-sectional study was conducted in the medicine outpatient department of Rajshahi Medical College Hospital, a tertiary care referral hospital from November 2020 to January 2021. All the adult patients (aged $\geq 18$ years) visiting the department with the diagnosis of asthma were the study population. The sample size was calculated from the following formula: $n=\frac{z^{2} p(1-p)}{d^{2}}$, where, $\mathrm{z}=1.96$ for $95 \%$ confidence level, $\mathrm{p}=$ assumed prevalence of poor adherence to inhaler therapy, $d=$ allowable error of assumed prevalence. Due to lack of existing evidence, we assumed the prevalence of adherence to inhaler therapy as $50 \%$ among the asthma patients of Bangladesh, and the calculated sample size was 384 . Assuming a 5\% non-response rate we approached a total of 400 patients. Patients aged $\geq 18$ years, had diagnosed asthma, and were using at least one metered-dose inhaler (MDI) with or without a spacer and/or dry powder inhaler (DPI) for at least one year were included in the study. Patients having asthmaCOPD overlap syndrome, other obstructive lung diseases, chronic debilitating conditions (e.g. carcinoma), women with pregnancy, and using inhalers for less than one year were excluded. The consecutive eligible patients during the study period were recruited until the targeted number of patients was reached. After excluding the incomplete data 357 patients were included in the final analysis.

\section{Data collection}

Face-to-face interview by five trained physicians after the consultation using a structured questionnaire and checklists was conducted to collect data from the patients and their medical records respectively. The questionnaire had four parts: (i) socio-demographic characteristics of the patients, (ii) information of inhalers they used and measurement of inhaler adherence, (iii) a demonstration session of their inhaler using technique to identify any critical error, and (iv) asthma control status using the Asthma Control Test (ACT) The questionnaire was prepared in English and translated to Bangla. Back 
translated version was compared with the original version to confirmed the equivalence across the language. A consortium was made to check the consistency of the translation and was pretested among 20 asthma patients before using it.

The 10-item Test of Adherence scale (TAI) based on a five-point Likert scale, which was developed and validated by Plaza et al. [18] and widely used in different countries $[19,20]$ were used to assess the inhaler adherence of asthma patients. However, the scale was not previously used among Bangladeshi patients, hence it was not previously validated. Patients are considered as good, intermediate, and poor adherents if they score 50, 46-49, and $\leq 45$ respectively $[18,19]$. In our study, poor adherence (TAI score $\leq 45$ ) was considered non-adherent.

Patients were requested to demonstrate their inhaler using technique and were scored in a checklist adapted from a previous study based on the recommendation of the American Thoracic Society according to the steps completed by the patients to identify any critical error [2].

\section{Outcome and independent variables}

Non-adherence to inhalers among asthma patients (TAI score $\leq 45)$ was the outcome variable of the present study. Independent variables were sociodemographic characteristics of the patients (age, sex, residence, educational status, family income, etc.), disease profile (smoking history, comorbidity, health-seeking behavior), and inhaler related information (type, number, and duration of inhaler usage, perceived difficulty and critical error of inhaler using technique, and self-reported efficacy of inhaler).

\section{Statistical analyses}

All the statistical analyses were made by using STATA version 16.0. Both univariable and multivariable logistic regression models adjusted for socio-demographic and inhaler-related factors were used to determine the predictors of poor adherence to inhalers of the asthma patients. The variance inflation factor (VIF) was used to detect any evidence of multicollinearity problem among independent variables. Statistical significance level was set at $p$-value $<0.05$ for a $95 \%$ confidence interval (CI).

\section{Ethical consideration}

Ethical approval was obtained from the ethical review committee of Rajshahi Medical College to conduct the study; Memo no: RMC-IRB-2020/178. Informed written consent was also obtained from each respondent after explaining the purpose of the study.

\section{Results}

\section{Characteristics of the participants}

A total of 357 asthma patients were included in the study. Their mean (SD) age was 34.5 (10.2) years. Almost twothirds of the participants were female $(65 \%)$ and hailing from rural areas (62\%). Almost half of them attended up to the secondary level of education and were from lowincome families. MDI was the most commonly used inhaler device by the patients $(75 \%$ without spacer and $13 \%$ with spacer) followed by DPI (12\%). In accounts of inhaler using duration, almost $20 \%$ were using an inhaler for less than one year, $47 \%$ for 2 to 5 years, and $33 \%$ for more than 5 years. Almost half of them preferred nonqualified practitioners for their regular respiratory problems (Table 1).

\section{Adherence to inhaler}

The Cronbach's Alpha of the TAI scale was 0.87 . The mean (SD) TAI score of the asthma patients was 36.5 (7.9). The majority of the patients (86\%) reported poor adherence to their inhalation therapy (TAI score $\leq 45$ ). Almost $8 \%$ of them reported good adherence (TAI score 50 ) and $6 \%$ showed moderate adherence (TAI score 46-49) (Table 1). Responses to each question on the TAI scale by the asthma patients are demonstrated in Table 2 .

Multivariable logistic regression models demonstrated that younger people were more chance to be non-adherent to their inhaler therapy (aOR 23.15, 95\% CI 3.67146.08 for patients aged from 18 to 30 and aOR 8.72, 95\% CI 1.62-46.85 for patients aged from 31 to 40 ). Besides, rural residence, less schooling year, and middle income were identified as significant predictors of non-adherence to inhaler (aOR 23.28, 95\% CI 2.43-222.66 for rural residence, aOR 5.69, 95\% CI 1.27-25.44 for schooling year $\leq 5$ years and aOR 9.74, 95\% CI 2.11-44.93 for middle income). Patients having comorbidities and using the inhaler for a longer period were more likely to be nonadherent to their therapy (aOR 12.91, 95\% CI 1.41-117.61 for having comorbidities and aOR 5.69, 95\% CI 1.2226.49 for using inhaler $>5$ years). Finally, patients visiting non-qualified practitioners (such as quacks, drug sellers, etc.) for their regular physical problems and reported inhaler using technique as difficult had a higher chance of non-adherence ((aOR 13.09, 95\% CI 3.10-55.26 and aOR $10.56,95 \%$ CI $2.95-37.73$ respectively) (Table 3 ).

\section{Discussion}

Adherence to the inhaler and the correct using technique of the device is crucial for asthma control. Our study provides a birds' eye view on the non-adherence to inhaler medication among the adult asthma patients of Bangladesh which exceeds $86 \%$. Existing evidence on this issue 
Table 1 Sociodemographic characteristics and inhaler adherence $(n=357)$

\begin{tabular}{|c|c|c|}
\hline Characteristics & Number & Percent \\
\hline \multicolumn{3}{|c|}{ Age (years) $($ mean $=34.54, S D=10.18)$} \\
\hline $18-30$ & 148 & 41.46 \\
\hline $31-40$ & 124 & 34.73 \\
\hline$>40$ & 85 & 23.81 \\
\hline \multicolumn{3}{|l|}{ Sex } \\
\hline Male & 232 & 64.99 \\
\hline Female & 125 & 35.01 \\
\hline \multicolumn{3}{|l|}{ Residence } \\
\hline Rural & 135 & 37.82 \\
\hline Urban & 222 & 62.18 \\
\hline \multicolumn{3}{|l|}{ Schooling year } \\
\hline$\leq 5$ & 68 & 19.05 \\
\hline $6-10$ & 119 & 33.33 \\
\hline$>10$ & 170 & 47.62 \\
\hline \multicolumn{3}{|l|}{ Family income } \\
\hline Low (<BDT 15000) & 196 & 54.90 \\
\hline Middle (BDT 15000 to 30,000 ) & 138 & 38.66 \\
\hline High (>BDT 30000) & 23 & 6.44 \\
\hline \multicolumn{3}{|l|}{ Smoking } \\
\hline Yes & 55 & 15.41 \\
\hline No & 302 & 84.59 \\
\hline \multicolumn{3}{|l|}{ Comorbidity } \\
\hline $\mathrm{DM}$ & 28 & 7.84 \\
\hline HTN & 41 & 11.48 \\
\hline CAD & 19 & 5.32 \\
\hline Others & 3 & 0.84 \\
\hline \multicolumn{3}{|l|}{ Number of inhaler } \\
\hline Single & 284 & 79.55 \\
\hline Multiple & 73 & 20.45 \\
\hline \multicolumn{3}{|l|}{ Device } \\
\hline MDI only & 270 & 75.63 \\
\hline MDI+Spacer & 46 & 12.89 \\
\hline DPI & 41 & 11.48 \\
\hline \multicolumn{3}{|l|}{ Duration of inhaler usage (years) } \\
\hline$\leq 5$ & 241 & 67.51 \\
\hline$>5$ & 116 & 32.49 \\
\hline \multicolumn{3}{|l|}{ Primary care seeking behavior } \\
\hline Non-qualified practitioner & 166 & 46.50 \\
\hline Qualified physician & 191 & 53.50 \\
\hline \multicolumn{3}{|c|}{ Demonstration of inhaler using technique } \\
\hline No & 127 & 35.57 \\
\hline Yes & 230 & 64.43 \\
\hline \multicolumn{3}{|l|}{ Difficulty of using inhaler } \\
\hline Very difficult & 28 & 7.84 \\
\hline Somewhat difficult & 178 & 49.86 \\
\hline Easy & 151 & 42.30 \\
\hline \multicolumn{3}{|l|}{ Self-reported efficacy of inhaler } \\
\hline Not effective & 21 & 5.88 \\
\hline Somewhat effective & 158 & 44.26 \\
\hline
\end{tabular}

Table 1 (continued)

\begin{tabular}{|c|c|c|}
\hline Characteristics & Number & Percent \\
\hline Effective & 178 & 49.86 \\
\hline \multicolumn{3}{|c|}{ Hospital admission due to respiratory problem during last 12 months } \\
\hline Yes & 79 & 22.13 \\
\hline No & 278 & 77.87 \\
\hline \multicolumn{3}{|l|}{ Critical error } \\
\hline Yes & 279 & 78.15 \\
\hline No & 78 & 21.85 \\
\hline \multicolumn{3}{|l|}{ Inhaler adherence } \\
\hline Overall TAI score & Mean $=36.45$ & $\mathrm{SD}=7.93$ \\
\hline Good adherence & 27 & 7.6 \\
\hline Moderate adherence & 21 & 5.9 \\
\hline Poor adherence & 309 & 86.5 \\
\hline
\end{tabular}

is scarce from this country to compare with. However, some recent studies from neighboring India reported the rate of poor adherence to inhalation therapy as $71 \%$ among adults and $55 \%$ among pediatric asthma patients $[21,22]$. Another study from some developing countries of Africa, like Ethiopia and Egypt, reported that almost half of the asthma patients were non-adherent to their medication $[9,23]$. Though these adherence rates were also suboptimal, the situation was quite better compared to ours. However, we used the self-reported 'Test of Adherence to Inhaler' scale, which was a subjective assessment and might overestimate the non-adherence. The TAI test yielded high rates of poor adherence even in developed countries. For example, the ASCONA study conducted among the asthma patients of Europe reported that almost $60 \%$ of patients were poor adherent to their prescribed therapy [24]. A recent study reported an almost $58 \%$ poor inhaler adherence rate using the 'TAI' scale, while the rate was $29 \%$ using the pharmacy refill records, which was a more objective scale [25]. However, another study from Denmark suggested that self-reported measurements overestimate the adherence rate and might not be used as a reliable indicator [26].

A number of personal and socioeconomic factors are reported to influence inhaler adherence among asthma patients. In our study, younger people were more likely to be non-adherent irrespective of their gender. A similar phenomenon was observed in a recent meta-analysis which reported that female and younger patients are more like to be non-adherent to their inhaler therapy [14]. In our study, the rural patients belonged to middleincome families and those who were using their inhalers for a longer period had a comparatively lower adherence rate than the urban patients. In contrast to our findings, a large-scale multi-country study from European asthma patients reported no such association of 
Table 2 Responses to the TAl questions by the asthma patients $(n=357)$

\begin{tabular}{|c|c|c|c|c|c|}
\hline \multirow[t]{2}{*}{ TAI questions } & \multicolumn{5}{|l|}{ Responses } \\
\hline & $\begin{array}{l}\text { All the time, } \\
\text { n (\%) }\end{array}$ & $\begin{array}{l}\text { More than half } \\
\text { of the time, } n \\
(\%)\end{array}$ & $\begin{array}{l}\text { About half of the time, } \\
\mathrm{n}(\%)\end{array}$ & $\begin{array}{l}\text { Less than } \\
\text { half of the } \\
\text { time, } \\
\mathrm{n}(\%)\end{array}$ & $\begin{array}{l}\text { None of the time, } \\
n(\%)\end{array}$ \\
\hline $\begin{array}{l}\text { How many times did you forget to take your regular } \\
\text { inhalers in the last } 7 \text { days? }\end{array}$ & $99(27.73)$ & 99 (27.73) & $115(32.21)$ & $40(11.20)$ & $4(1.12)$ \\
\hline \multirow{2}{*}{ You forget to take your inhalers } & $86(24.09)$ & 87 (24.37) & 75 (21.01) & 101 (28.29) & $8(2.24)$ \\
\hline & $\begin{array}{l}\text { Always } \\
\text { n (\%) }\end{array}$ & $\begin{array}{l}\text { Almost always } \\
\mathrm{n}(\%)\end{array}$ & $\begin{array}{l}\text { Sometimes } \\
\text { n (\%) }\end{array}$ & $\begin{array}{l}\text { Almost never } \\
\mathrm{n}(\%)\end{array}$ & $\begin{array}{l}\text { Never } \\
\mathrm{n}(\%)\end{array}$ \\
\hline $\begin{array}{l}\text { When you are feeling well, you stop taking your } \\
\text { inhalers }\end{array}$ & $67(18.77)$ & $59(16.53)$ & $80(22.41)$ & $102(28.57)$ & $49(13.73)$ \\
\hline $\begin{array}{l}\text { At the weekend or when you go on holiday, you } \\
\text { stop taking your inhalers }\end{array}$ & 93 (26.05) & $70(19.61)$ & 69 (19.33) & 96 (26.89) & $29(8.12)$ \\
\hline $\begin{array}{l}\text { When you are anxious or sad, you stop taking your } \\
\text { inhalers }\end{array}$ & $134(37.54)$ & $108(30.25)$ & $60(16.81)$ & $35(9.80)$ & $20(5.60)$ \\
\hline $\begin{array}{l}\text { You don't take your inhalers out of fear of potential } \\
\text { side effects }\end{array}$ & $177(49.58)$ & $116(32.49)$ & $37(10.36)$ & $23(6.44)$ & $4(1.12)$ \\
\hline $\begin{array}{l}\text { You stop taking your inhalers because you believe } \\
\text { that they are of little help in treating your disease }\end{array}$ & $196(54.90)$ & $82(22.97)$ & $47(13.17)$ & $30(8.40)$ & $2(0.56)$ \\
\hline $\begin{array}{l}\text { You take fewer inhalations than prescribed by your } \\
\text { doctor }\end{array}$ & $85(23.81)$ & $53(14.85)$ & $100(28.01)$ & 99 (27.73) & $20(5.60)$ \\
\hline $\begin{array}{l}\text { You stop taking your inhalers because you believe } \\
\text { that they interfere with your day-to-day or work life }\end{array}$ & $160(44.82)$ & $81(22.69)$ & 65 (18.21) & $47(13.17)$ & $4(1.12)$ \\
\hline $\begin{array}{l}\text { You stop taking your inhalers because you have } \\
\text { trouble paying for them }\end{array}$ & $129(36.13)$ & $56(15.69)$ & $88(24.65)$ & $63(17.65)$ & $21(5.88)$ \\
\hline
\end{tabular}

these factors with inhaler adherence [13]. Though some studies suggested that patients using DPI devices had better adherence to their inhalers [27, 28], our finding did not support that. However, a very small number of patients in our study were using DPI to conclude. Besides, patients who visited non-qualified practitioners for their regular respiratory problems had more chances to be non-adherent to their therapies. A similar finding was reported by a study among inhalers using COPD patients that reported that patients who received primary care from feedback from non-qualified care providers were less sustained in medication adherence [29]. Our study suggests that asthma patients with comorbidities have a higher chance to be non-adherent. These patients showed less adherence in some previous studies too [30, 31]. Having comorbidities like diabetes, hypertension, coronary artery diseases, etc. often increase the pill burden and cost of treatment which influences the patients to be ignorant to their prescription, especially in the resource-poor socioeconomic setting. Besides these, patients' belief and perception about the disease and its severity, self-care ability, family and social support, communication quality with healthcare providers as well as perceived efficacy of the therapy was reported as influencing factor for inhaler adherence in several studies $[11,12,14,32-35]$. These factors were not explored extensively in our study. However, patients who reported inhaler using technique as difficult had a higher chance of non-adherence. Further qualitative studies addressing the patients' behavioral factors and perceived barriers for inhaler adherence is necessary for better understanding. A multidisciplinary approach to support the patient both mentally and physically shared decision making between provider and patients based on possible risk and benefits could better the inhaler adherence.

The ASCONA study conducted among a large European asthma cohort reported that patients having good adherence to their inhaler therapies had better asthma control irrespective of age, sex, comorbidity and treatment modality [24]. Another large scale cohort study reported that asthma patients maintaining high adherence to their inhalers over time, had a better control of asthma [36]. Moreover, a recent review of published articles on this topic reported that good adherence to inhalers decreased the number and frequency of severe asthma exacerbations in high-quality studies [37]. Based on this evidence, it may be concluded that adherence to inhalers is a major contributor to asthma control.

\section{Limitations}

Our study had several limitations. Firstly, it was conducted among the patients with asthma who visited the 
Table 3 Factors associated with non-adherence to inhalers among asthma patients (univariable and multivariable logistic regression models)

\begin{tabular}{|c|c|c|}
\hline Variables & Non-adherence, $\mathrm{n}(\%)$ & aOR $(95 \% \mathrm{Cl})$ \\
\hline \multicolumn{3}{|l|}{ Age (years) } \\
\hline $18-30$ & $140(94.59)$ & $23.15(3.67-146.08)^{\prime}$ \\
\hline $31-40$ & $103(83.06)$ & $8.72(1.62-46.85)^{*}$ \\
\hline$>40$ & $66(77.65)$ & 1 \\
\hline \multicolumn{3}{|l|}{ Sex } \\
\hline Male & $206(88.79)$ & $1.06(0.28-3.96)$ \\
\hline Female & $103(82.40)$ & 1 \\
\hline \multicolumn{3}{|l|}{ Residence } \\
\hline Rural & $131(97.04)$ & $23.28(2.43-222.66)^{\prime \prime}$ \\
\hline Urban & $178(80.18)$ & 1 \\
\hline \multicolumn{3}{|l|}{ Schooling year } \\
\hline$\leq 5$ & $62(91.18)$ & $5.69(1.27-25.44)^{*}$ \\
\hline $6-10$ & $101(84.87)$ & $2.76(0.69-11.08)$ \\
\hline$>10$ & $146(85.88)$ & 1 \\
\hline \multicolumn{3}{|l|}{ Family income } \\
\hline Low (<BDT 15000) & $155(79.08)$ & 1 \\
\hline Middle (BDT 15000 to 30,000) & $134(97.10)$ & $9.74(2.11-44.93)^{*}$ \\
\hline High (>BDT 30000) & $20(86.96)$ & $3.57(0.17-74.68)$ \\
\hline \multicolumn{3}{|l|}{ Smoking } \\
\hline Yes & $43(78.18)$ & $0.51(0.10-2.61)$ \\
\hline No & $266(88.08)$ & 1 \\
\hline \multicolumn{3}{|l|}{ Comorbidity } \\
\hline Yes & $42(84.00)$ & $12.91(1.41-117.61)^{*}$ \\
\hline No & $267(86.97)$ & 1 \\
\hline \multicolumn{3}{|l|}{ Number of inhaler } \\
\hline Single & $251(88.38)$ & $0.92(0.26-3.24)$ \\
\hline Multiple & $58(79.45)$ & 1 \\
\hline \multicolumn{3}{|l|}{ Device } \\
\hline MDI only & $233(86.30)$ & $0.56(0.14-2.22)$ \\
\hline MDI+Spacer & $43(93.48)$ & $2.81(0.11-68.68)$ \\
\hline DPI & $33(80.49)$ & 1 \\
\hline \multicolumn{3}{|l|}{ Duration of inhaler usage (years) } \\
\hline$\leq 5$ & $197(81.74)$ & 1 \\
\hline$>5$ & $112(96.55)$ & $5.69(1.22-26.49)^{*}$ \\
\hline \multicolumn{3}{|l|}{ Primary care seeking behavior } \\
\hline Non-qualified practitioner & $160(96.39)$ & $13.09(3.10-55.26)^{*}$ \\
\hline Qualified physician & $149(78.01)$ & 1 \\
\hline \multicolumn{3}{|c|}{ Demonstration of inhaler using technique } \\
\hline No & $117(92.13)$ & $1.32(0.32-5.39)$ \\
\hline Yes & $192(83.48)$ & 1 \\
\hline \multicolumn{3}{|l|}{ Difficulty of using inhaler } \\
\hline Very difficult & $26(92.86)$ & $5.56(0.73-42.27)$ \\
\hline Somewhat difficult & $169(94.94)$ & $10.56(2.95-37.73)^{*}$ \\
\hline Easy & $114(75.50)$ & 1 \\
\hline \multicolumn{3}{|l|}{ Self-reported efficacy of inhaler } \\
\hline Effective & $154(86.52)$ & $2.64(0.36-19.51)$ \\
\hline Somewhat effective & $138(87.34)$ & $2.79(0.35-22.36)$ \\
\hline Not effective & $17(80.95)$ & 1 \\
\hline \multicolumn{3}{|l|}{ Critical error } \\
\hline Yes & $256(91.76)$ & $1.49(0.45-5.00)$ \\
\hline No & $53(67.95)$ & 1 \\
\hline
\end{tabular}

${ }^{*} p$-value $<0.05$ 
hospital outdoor for their exacerbation or other issues and so, the findings could not be inferential for the overall patient population from the community. Moreover, we used a self-reported adherence measuring tool that could potentially underestimate the non-adherence rate to inhalers as social desirability bias could not be rolled out. Some of our variables showed bizarre odds ratios in the logistic regression model which needs cautious interpretetion. Heterogeneity in the patient sample might result in these findings. More cautious inclusion criteria should be adopted in future studies. Finally, a detailed exploration of the perceived barriers of the patients was not explored extensively.

\section{Conclusions}

Despite being an important contributing factor to asthma control, the adherence rate to the inhalers was poor among our patients. Regular investigation for patients' adherence to the prescribed inhalers is necessary for patients with uncontrolled asthma. Adequate patient education and counseling about the nature of disease and the importance of regular use of inhalers as well as encouraging patients to seek treatment from qualified physicians is suggested to improve inhaler adherence.

\section{Acknowledgements}

The authors acknowledge the support of the outdoor physicians of Rajshahi Medical College Hospital in facilitating the data collection process.

\section{Authors' contributions \\ Conceptualization: MAR, KA, MJH, MAH, MGH, Formal analysis: MAR, MJH, MGH, Investigation: CIT, ST, AB, FJ, SJM, ABS, SS, AR, MM, NN, TS, ARM, Meth- odology: MAR, KA, MJH, MAH, MGH, Resources: MJH, MAH, MGH, Supervision: MAH, MJH. MGH, Writing - original draft: MAR, CIT, TS, MJH, MAH, Writ- ing - review \& editing: MAR, MJH. All authors read and approved the final manuscript.}

\section{Funding}

This Study has not received any fund.

\section{Availability of data and materials}

The data are available from the corresponding author on reasonable request.

\section{Declarations}

\section{Ethics approval and consent to participate}

Ethical approval was obtained from the ethical review committee of Rajshahi Medical College to conduct the study. Informed written consent was also obtained from each respondent after explaining the purpose of the study.

\section{Consent for publication}

Not applicable.

\section{Competing interests}

The authors declare that they have no competing interests.

\section{Author details}

${ }_{1}^{1}$ Rajshahi Medical College, Rajshahi, Bangladesh. ${ }^{2}$ Pi Research Consultancy Center, Dhaka, Bangladesh. ${ }^{3}$ Chittagong Medical College, Chittagong,
Bangladesh. ${ }^{4}$ North South University, Dhaka, Bangladesh. ${ }^{5}$ Save the Children Bangladesh, Dhaka, Bangladesh. ${ }^{6}$ Banshkhali Upazila health complex, Chittagong, Bangladesh. ${ }^{7}$ M Abdur Rahim Medical College, Dianjpur, Bangladesh. ${ }^{8}$ Shaheed Suhrawardy Medical College, Dhaka, Bangladesh. ${ }^{9}$ Sir salimullah medical college, Dhaka, Bangladesh. ${ }^{10}$ Khulna Medical College, Khulna, Bangladesh. ${ }^{11}$ Central Medical College, Cumilla, Bangladesh. ${ }^{12}$ Dhaka Medical College, Dhaka, Bangladesh. ${ }^{13}$ University of Rajshahi, Rajshahi, Bangladesh.

Received: 13 January 2022 Accepted: 3 February 2022

Published online: 09 February 2022

\section{References}

1. Global Strategy for Asthma Management and Prevention [Internet]. 2021 [cited 2022 Feb 1]. Available from: https://ginasthma.org/wp-content/ uploads/2021/05/GINA-Main-Report-2021-V2-WMS.pdf

2. Viegi G, Maio S, Fasola S, Baldacci S. Global Burden of Chronic Respiratory Diseases. J Aerosol Med Pulm Drug Deliv. 2020;33(4):171-7 Available from: https://pubmed.ncbi.nlm.nih.gov/32423274/. [cited 2022 Feb 1].

3. Global Asthma Network. The Global Asthma report (2018) [Internet]. 2018 [cited 2021 Jul 9]. Available from: https://scholar.google.com/scholar? $\mathrm{hl}=$ en\&as _sdt=0\%2C5\&q=Global+Asthma+Network. $+\% 282018 \% 29 .+$ the+Global+Asthma+Report+2018.+In+Auckland\%2C+New+Zeala nd\&btnG $=$.

4. Braman SS. The Global Burden of Asthma. Chest. 2006;130(1):4S-12S Available from: http://journal.chestnet.org/article/S0012369215329524/ fulltext. [cited 2021 Oct 22].

5. Bishwajit G, Tang S, Yaya S, Feng Z. Burden of asthma, dyspnea, and chronic cough in South Asia. Int J Chron Obstruct Pulmon Dis. 2017;12:1093 Available from:/pmc/articles/PMC5388281/. [cited 2021 Jul 9].

6. Borghardt JM, Kloft C, Sharma A. Inhaled therapy in respiratory disease: the complex interplay of pulmonary kinetic processes. Can Respir J. 2018:2018 Available from:/pmc/articles/PMC6029458/. [cited 2021 Jul 9].

7. Bateman ED, Hurd SS, Barnes PJ, Bousquet J, Drazen JM, FitzGerald M, et al. Global strategy for asthma management and prevention: GINA executive summary. Eur Respir J. 2008;31(1):143-78 Available from: https://erj.ersjournals.com/content/31/1/143. [cited 2021 Oct 22].

8. Reddel HK, Bacharier LB, Bateman ED, Brightling CE, Brusselle GG, Buhl R, et al. Global Initiative for Asthma (GINA) Strategy 2021 - Executive summary and rationale for key changes. Eur Respir J. 2021:2102730 Available from: https://erj.ersjournals.com/content/early/2021/10/14/13993003. 02730-2021. [cited 2021 Oct 22].

9. Ayele AA, Tegegn HG. Non adherence to inhalational medications and associated factors among patients with asthma in a referral hospital in Ethiopia, using validated tool TAl. Asthma Res Pract. 2017;3(1):1-6 Available from: https://link.springer.com/articles/10.1186/s40733-017-0035-0. [cited 2021 Jul 15].

10. Heaney LG, Horne R. Non-adherence in difficult asthma: time to take it seriously. Thorax. 2012;67(3):268-70 Available from: https://thorax.bmj. com/content/67/3/268. [cited 2021 Jul 30].

11. Gamble J, Stevenson M, Heaney LG. A study of a multi-level intervention to improve non-adherence in difficult to control asthma. Respir Med. 2011;105(9):1308-15 Available from: http://www.resmedjournal.com/ article/S0954611111001090/fulltext. [cited 2021 Jul 30].

12. Gamble J, Stevenson M, McClean E, Heaney LG. The Prevalence of Nonadherence in Difficult Asthma. 2012;180(9):817-22. Available from: www.atsjournals.org. [cited 2021 Jul 30]. https://doi.org/10.1164/rccm2 00902-01660C

13. Corsico AG, Cazzoletti L, de Marco R, Janson C, Jarvis D, Zoia MC, et al. Factors affecting adherence to asthma treatment in an international cohort of young and middle-aged adults. Respir Med. 2007;101(6):1363-7 Available from: http://www.resmedjournal.com/article/S09546111060059 93/fulltext. [cited 2021 Jul 30].

14. Hassan M, Davies SE, Trethewey SP, Mansur AH. Prevalence and predictors of adherence to controller therapy in adult patients with severe/ difficult-to-treat asthma: a systematic review and meta-analysis. 2019;57(12):1379-88. Available from: https://www.tandfonline.com/doi/ abs/10.1080/02770903.2019.1645169. [cited 2021 Jul 30]. https://doi.org/ $10.1080 / 0277090320191645169$. 
15. Peters SP, Ferguson G, Deniz Y, Reisner C. Uncontrolled asthma: a review of the prevalence, disease burden and options for treatment. Respir Med. 2006;100(7):1139-51.

16. Chen S, Golam S, Myers J, Bly C, Smolen H, Xu X. Systematic literature review of the clinical, humanistic, and economic burden associated with asthma uncontrolled by GINA Steps 4 or 5 treatment. 2018;34(12):207588. Available from: https://www.tandfonline.com/doi/abs/10.1080/03007 995.2018.1505352. [cited 2021 Jul 10]. https://doi.org/10.1080/03007 99520181505352

17. Lindsay JT, Heaney LG. Nonadherence in difficult asthma \&ndash; facts, myths, and a time to act. Patient Prefer Adherence. 2013;7:329-36 Available from: https://www.dovepress.com/nonadherence-in-difficultasthma-ndash-facts-myths-and-a-time-to-act-peer-reviewed-fulltext-artic le-PPA. [cited 2021 Oct 22].

18. Plaza V, Fernández-Rodríguez C, Melero C, Cosío BG, Entrenas LM, De Llano LP, et al. Validation of the "Test of the Adherence to Inhalers" (TAI) for Asthma and COPD Patients. J Aerosol Med Pulm Drug Deliv. 2016;29(2):142-52 Available from: https://pubmed.ncbi.nlm.nih.gov/ 26230150/. [cited 2021 May 23].

19. Montes De Oca M, Menezes A, Wehrmeister FC, Lopez Varela MV, Casas A, Ugalde L, et al. Adherence to inhaled therapies of COPD patients from seven Latin American countries: The LASSYC study. PLoS One. 2017;12(11):e0186777. https://doi.org/10.1371/journal.pone.0186777 [cited 2021 may 23].

20. Muneswarao J, Hassali MA, Ibrahim B, Saini B, Naqvi AA, Ali IAH, et al. Translation and validation of the Test of Adherence to Inhalers (TAI) questionnaire among adult patients with asthma in Malaysia. 2020. https:// doi.org/10.1080/0277090320201776728 Available from: https://www. tandfonline.com/doi/abs/10.1080/02770903.2020.1776728. [cited 2021 Jul 15].

21. Santhakumar S. Assessment of adherence to inhalers in asthmatics. Pulmon. 2021;23(1):7 Available from: https://www.pulmon.in/index.php/ pulmon/article/view/10. [cited 2021 Jul 15].

22. Sinha R, Lahiry S, Ghosh S. Suboptimal compliance to aerosol therapy in pediatric asthma: a prospective cohort study from eastern India. Lung India. 2019;36(6):512 Available from: /pmc/articles/PMC6852208/. [cited 2021 Jul 15].

23. Ali AHK, Ameen E, Atta K, Alkhayat KF. Drug-related factors affecting medication adherence among Egyptian asthma patients. Egypt J Bronchol. 2020;14(1):1-7 Available from: https://ejb.springeropen.com/artic les/10.1186/s43168-020-00035-w. [cited 2021 Jul 15].

24. Pereyra FG, Plaza V, Bustamante V, Calle M, Contreras FJ, Giner J, et al. Control of asthma, adherence to inhaled therapy and usefulness of the Test of Adherence to Inhalers (TAI). Results of the ASCONA study. Eur Respir J. 2017;50(suppl 61):PA534 Available from: https://erj.ersjournals.com/conte nt/50/suppl_61/PA534. [cited 2021 Jul 15].

25. Plaza V, Giner J, Curto E, Alonso-Ortiz MB, Orue MI, Vega JM, et al. Assessing adherence by combining the test of adherence to inhalers with pharmacy refill records. J Investig Allergol Clin Immunol. 2021;31(1):58-64 Available from: https://europepmc.org/article/med/31599726. [cited 2021 May 23].

26. Jensen FF, Håkansson KEJ, Overgaard Nielsen B, Weinreich UM, Ulrik CS. Self-reported vs. objectively assessed adherence to inhaled corticosteroids in asthma. Asthma Res Pract. 7(1):1-9 Available from: https://asthm arp.biomedcentral.com/articles/10.1186/s40733-021-00072-2. [cited 2021 Jul 30].

27. Roy A, Battle K, Lurslurchachai L, Halm EA, Wisnivesky JP. Inhaler device, administration technique, and adherence to inhaled corticosteroids in patients with asthma. Prim Care Respir J. 2011;20(2):148-54 Available from: https://www.nature.com/articles/pcri201122. [cited 2021 Jul 30].

28. Crompton GK. How to achieve good compliance with inhaled asthma therapy. Respir Med. 2004;98(SUPPL. 2):S35-40.

29. Humenberger M, Horner A, Labek A, Kaiser B, Frechinger R, Brock C, et al Adherence to inhaled therapy and its impact on chronic obstructive pulmonary disease (COPD). BMC Pulm Med. 2018;18(1):1-6 Available from: https://bmcpulmmed.biomedcentral.com/articles/10.1186/s12890018-0724-3. [cited $2021 \mathrm{Jul} 30$ ]

30. Kebede B, Mamo G. Determinants of non-adherence to inhaled steroids in adult asthmatic patients on follow up in referral hospital, Ethiopia: cross-sectional study. Asthma Res Pract. 2019;5(1):1-8 Available from: https://asthmarp.biomedcentral.com/articles/10.1186/s40733-019-00531. [cited 2021 Jul 30].

31. Ayele AA, Tegegn HG. Non adherence to inhalational medications and associated factors among patients with asthma in a referral hospital in Ethiopia, using validated tool TAl. Asthma Res Pract. 2017:3(1):1-6 Available from: https://asthmarp.biomedcentral.com/articles/10.1186/s40733017-0035-0. [cited 2021 Jul 30].

32. Vrijens B, Dima AL, Van Ganse E, van Boven JFM, Eakin MN, Foster JM, et al What we mean when we talk about adherence in respiratory medicine. J Allergy Clin Immunol Pract. 2016;4(5):802-12.

33. Amin S, Soliman M, Mclvor A, Cave A, Cabrera C. $<p>$ Understanding Patient Perspectives on Medication Adherence in Asthma: A Targeted Review of Qualitative Studies $</ p>$. Patient Prefer Adherence [Internet]. 2020 Mar 10 [cited 2021 Jul 30];14:541-51. Available from: https://www dovepress.com/understanding-patient-perspectives-on-medicationadherence-in-asthma-a-peer-reviewed-fulltext-article-PPA

34. Dima AL, Hernandez G, Cunillera O, Ferrer M, de Bruin M, group the A-L. Asthma inhaler adherence determinants in adults: systematic review of observational data. Eur Respir J. 2015;45(4):994-1018 Available from: https://erj.ersjournals.com/content/45/4/994. [cited 2021 Jul 30].

35. Bender BG, Bender SE. Patient-identified barriers to asthma treatment adherence: responses to interviews, focus groups, and questionnaires. Immunol Allergy Clin N Am. 2005;25(1):107-30.

36. Dima AL, van Ganse E, Stadler G, de Bruin M. Does adherence to inhaled corticosteroids predict asthma-related outcomes over time? A cohort study. Eur Respir J. 2019;54(6):1900901 Available from: https://erj.ersjo urnals.com/content/54/6/1900901. [cited 2021 Jul 30].

37. Engelkes M, Janssens HM, de Jongste JC, Sturkenboom MCJM, Verhamme KMC. Medication adherence and the risk of severe asthma exacerbations: a systematic review. Eur Respir J. 2015;45(2):396-407 Available from: https://erj.ersjournals.com/content/45/2/396. [cited 2021 Jul 30].

\section{Publisher's Note}

Springer Nature remains neutral with regard to jurisdictional claims in published maps and institutional affiliations.

Ready to submit your research? Choose BMC and benefit from

- fast, convenient online submission

- thorough peer review by experienced researchers in your field

- rapid publication on acceptance

- support for research data, including large and complex data types

- gold Open Access which fosters wider collaboration and increased citations

- maximum visibility for your research: over 100M website views per year

At BMC, research is always in progress.

Learn more biomedcentral.com/submissions 